doi: 10.7546/BL.LXV.18.03.11

\title{
ЕЗИКОВА КУЛТУРА
}

\section{ЗА РАЗЛИЧНИТЕ УПОТРЕБИ НА ДУМАТА ОБЩИНА И ГРАФИЧНОТО ИМ РАЗГРАНИЧАВАНЕ}

ЛОРА МИКОВА

ИНСТИТУТ ЗА БЪЛГАРСКИ ЕЗИК „ПРОФ. Л. АНДРЕЙЧИН““ПРИ БАН

mikova.lora@gmail.com

Думата община може да се пише с главна или с малка буква в зависимост от употребата. Когато е собствено име на конкретна институция, се пише с главна буква. В останалите случаи - като съществително нарицателно за назоваване на административно-териториална единица, на орган на местното самоуправление или на сградата, в която се намира администрацията на тази институция - се употребява малка буква.

В практиката думата община се среща изписана както с малка, така и с главна буква. Често се появяват затруднения кога думата трябва да се напише с малка и кога с главна буква, защото може да има различни употреби - като съществително нарицателно име или като собствено име. Когато е употребена за назоваване на административно-териториална единица, се пише с малка буква като съществително нарицателно: В община Сливен има над 40 селища; Ремонтират пътищата в община Габрово.

Думата община може да назовава и орган на местното самоуправление, институция. В този случай, ако е употребена като съществително нарицателно име и не е част от собственото име на конкретната институция, думата се пише с малка буква, например: Всяка община си има кмет. Заявления се подават в съответните общини (срв. и Зависи от решенията на съответните министерства; Номинираните лица се определят по установените за всяко министерство процедури; но: Такова е решението на Министерството на здравеопазването).

Често обаче община е пьрва част на собственото име на конкретна институция и в този случай се пише с главна буква: Днес Община Пловдив прие нова наредба за регистращия на кучетата; В Община Бургас постьпи протстно писмо от граждани. Договорът е сключен с Община Сливен.

Необходимостта думата община да се изписва с главна или малка буква в зависимост от това какво точно се означава - административно-териториална единица (подобно например на област) или име на конкретна институция - е възникнала естествено. Разликата между двете употреби (и съответно изписване) на думата личи ясно в следните два примера: рабо- 
тещите в община Самоков и работещите в Община Самоков - в първия случай става въпрос за тези, които работят на територията на цялата община, във всичките населени места, които обхваща, докато във втория случай се има предвид само общинската администрация, служителите в институцията.

Писането на главна или малка буква при думата община е според общото правило на с. 40 от Офичиалния правописен речник на българския език (2012): „Морфологичната употреба на главни и малки букви разграничава графично собствените имена от останалите думи вътре в изречението“. Когато община е първа част от съставно собствено име, се пише с главна буква, тъй като съставните собствени имена се пишат с начална главна буква: Община Шумен, Община Плевен, срв. и Република България, Министерство на културата. Когато съставното собствено име е съкратено до едносъставно собствено име, то също се пише с главна буква: Общината вм. Община Варна, Министерството вместо Министерство на образованието и науката. Например: Трябва да изпратите писмо до отдел „Гражданска регистрачия и състояние“ на Общината - има се предвид конкретна община, чието съставно собствено име е съкратено до едносъставно; главната буква се пише, за да се запази връзката със собственото име.

Подобни правописни колебания възникват и при други съществителни нарицателни имена, които се употребяват и като първа част на съставни собствени имена. В зависимост от употребата си те се пишат с малка или с главна буква. Освен вече споменатите община и министерство, колебания съществуват и при думи като посолство, закон и др. Когато са употребени като първа съставна част на собствено име на конкретна институция, документ и под., те се пишат с главна буква: Посолство на Република България в Швеция, Закон за горите. В случай че не става въпрос за конкретната институция, документ и под., тогава съответните думи не се използват като собствени имена и се пишат с малка буква: Той би искал да работи в посолство; Не знам в кой закон е написано това; Чудя се в коя община е работил, дали в Община Сандански, или в Община Петрич (но: Чудя се в коя община е работил, дали в общината в Сандански, или в общината в Петрич - тук не се използват собствените имена, а съществителното нарицателно име община в значение 'орган на местното самоуправление'; общината не замества Община Сандански и Община Петрич, иначе би се получил израз, който не се употребява: *в Община Сандански в Сандански).

Понякога употребата на главна или малка буква зависи от намерението на автора. Ако той иска да каже, че е подал заявление до Община Видин, но използва ськратеното име - Общината, тогава ще напише: Подадох заявление до Общината. Ако обаче авторьт няма предвид собственото име, а просто иска да каже, че е подал заявление до общината, до институцията, управляваща селището, в което той живее, съответно ще напише: Подадох заявление до общината. Употребата на главна или малка буква тук зависи 
от това какво иска да изрази авторьт, дали иска да запази връзката със собственото име, или просто назовава вида институция.

Трябва да се отбележи, че освен административно-териториалната единица и институцията с думата община може да се назовава също така и сградата, в която се помещава администрацията на институцията. В този случай общзина се пише с малка буква, тъй като не представлява част от собствено име. Например: Уговорихме си срещуа пред общчината.

\section{РЕЗЮМЕ}

Думата общзина може да се пише с главна или с малка буква в зависимост от употребата. Когато е собствено име на конкретна институция, се пише с главна буква. В останалите случаи - като съществително нарицателно за назоваване на административно-териториална единица, на орган на местното самоуправление или на сградата, в която се намира администрацията на тази институция - се употребява малка буква.

$\triangle$ Ас. Лора Микова Секция за съвременен български език Институт за български език „Проф. Л. Андрейчин“ при БАН бул. „Шипченски проход“ ”2, бл. 17, 1113 София, България

Публикувано: 30 септември 2018 